\title{
$\mathrm{ZnO}-\mathrm{Nb}_{2} \mathrm{O}_{5}$ 系セラミックスの電気的性質と微構造に 及ぼす添加剂の影響
}

\author{
佐谷野顕生*・中川善兵衛 - 浜 野 健 也 \\ 東京工業大学 工業材料研究所 \\ *現在 東京芝浦電気 (株) 金属材料事業部)
}

$1 \mathrm{~mol} \%$ の $\mathrm{Nb}_{2} \mathrm{O}_{5}$ を含む $\mathrm{ZnO}$ セラミックスに，焼成時に生成する液相の性質及び液相と固相の 相互関係を変化させる目的で第 3 成分 $\left(\mathrm{CaO}, \mathrm{SrO}, \mathrm{BaO}, \mathrm{SiO}_{2}, \mathrm{CoO}, \mathrm{MnO}\right)$ を添加し, これら が焼成体の電気的性質亡微構造に与える影響について検討した。

$\mathrm{CaO}, \mathrm{SrO}, \mathrm{BaO}$ の添加は $\mathrm{ZnO}$ 粒子に対する粒界相のぬれ性を良くし，焼成体の比抵抗を増加 させた. $\mathrm{SiO}_{2}$ の添加は粒界相の好性を良くするが比抵抗の值には変化を与えなかった．CoOの 添加は電気的性質, 微構造にほとんど影響しなかった. $\mathrm{MnO}$ の添加は焼成体の組織にそれほど变 化を与えないが，添加量の増加とともに比抵抗は急激に増加し， $0.5 \mathrm{~mol} \%$ の添加でバリスタ一特 性が認められた。

$\mathrm{ZnO}$ に $0.5 \mathrm{~mol} \%$ の $\mathrm{MnO}$ のみを添加した焼成体も比抵抗が高く, 若干のバリスタ一特性が認め られた。これに $\mathrm{Nb}_{2} \mathrm{O}_{5}$ を少量添加すると比抵抗值は急激に減少するが， $\mathrm{Nb}_{2} \mathrm{O}_{5}$ の添加量が $1 \mathrm{~mol} \%$ になると再び比抵抗值は高くなってバリスター特性が現れた. $\mathrm{MnO}$ のみ添加した焼成体のバリ ス夕一特性は $\mathrm{ZnO}$ 粒界に $\mathrm{MnO}$ が析出するためと推定され，これに $\mathrm{Nb}_{2} \mathrm{O}_{5}$ を添加した焼成体のも のは液相の生成と関連するものと考えられた。

(1983 年 4 月 25 日受付)

\section{Effect of Additives on the Electrical Properties and Microstructure of $\mathrm{ZnO}-\mathrm{Nb}_{2} \mathrm{O}_{5}$ Ceramics}

\author{
Akio SAYANO*, Zenbe-e NAKAGAWA and Kenya HAMANO \\ Research Laboratory of Engineering Materials, Tokyo Institute of Technology \\ 4259, Nagatsuta, Midori-ku, Yokohama-shi 227 \\ *Now with Metal Products Div., Toshiba Corp.
}

The third component $\left(\mathrm{CaO}, \mathrm{SrO}, \mathrm{BaO}, \mathrm{SiO}_{2}, \mathrm{CoO}\right.$ and $\mathrm{MnO}$ ) was added to $\mathrm{ZnO}$ ceramics containing $1 \mathrm{~mol} \% \mathrm{Nb}_{2} \mathrm{O}_{5}$ in order to alter the property of melts formed during firing, and the electrical resistivity, $V-I$ relation and microstructure of sintered bodies were examined. The addition of $\mathrm{CaO}, \mathrm{SrO}$ and $\mathrm{BaO}$ improved the wetting of intergranular layers to $\mathrm{ZnO}$ grains and increased the room-temperature electrical resistivity. The addition of $\mathrm{SiO}_{2}$ also improved the wetting, but did not affect the electrical property. CoO gave no changes to the fired body. Although it did not strongly affect the microstructure, the addition of $\mathrm{MnO}$ markedly increased the room-temperature resistivity and gave rise to nonlinear $V-I$ relation. The $\mathrm{ZnO}$ specimen containing only $\mathrm{MnO}$ also showed high electrical resistivity and some nonlinear $V-I$ relation. The addition of a small amount of $\mathrm{Nb}_{2} \mathrm{O}_{5}$ to $\mathrm{ZnO}-\mathrm{MnO}$ system strikingly decreased the electrical resistivity, but an increase in the amount of $\mathrm{Nb}_{2} \mathrm{O}_{5}$ addition $(1 \mathrm{~mol} \%$ ) enhanced again the electrical resistivity and led to a nonlinear $V-I$ characteristic.

[Received April 25, 1983]

Key-words : $\mathrm{ZnO}-\mathrm{Nb}_{2} \mathrm{O}_{5}$ ceramics, Electrical resistivity, Microstructure, Wettability, Additive, $\mathrm{MnO}$, Nonlinear $V-I$ characteristic 


\section{1. 緒言}

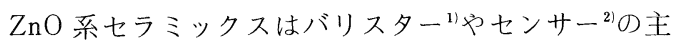
成分として使用されており，その中でもバリスターはセ ラミックスの粒界を積極的に利用した画期的なセラミッ クスである ${ }^{31}$. バリスターの電気的性質はその微構造に 大きく依存することが知られており ${ }^{4}$, その微構造をコ ントロールすることは極めて重要なことである.しかし 実際に実用化されている $\mathrm{ZnO}$ バリスタ一は高い非直線 性を達成するため, 同時に多くの添加物が添加されてお り，そのため微構造が複雑で解析が困難である。またそ の基礎的な研究においては, $\mathrm{ZnO}-\mathrm{Bi}_{2} \mathrm{O}_{3}{ }^{5)-81}$ や $\mathrm{ZnO}$ $\mathrm{Sb}_{2} \mathrm{O}_{3}{ }^{9}$ などの 2 成分系のものもあるが, 多くは高い非 直線性をもつ多成分系に関するものである. 微構造コン トロールの基礎的な研究には，できるだけ単純化した系 について行うことが重要であると思われる.

著者らは $\mathrm{ZnO}-\mathrm{Nb}_{2} \mathrm{O}_{5}$ 系を中心にその微構造と電気的 性質の関係について研究を進めているが ${ }^{10)}$, 本報では焼 成中に生成する液相の性質, 並びに液相と固相の相互関 係を制御する目的で $\mathrm{ZnO}-\mathrm{Nb}_{2} \mathrm{O}_{5}$ 系に第 3 成分を添加 し, これらの添加物の挙動や焼成体の微構造, 電気的性 質に与える影響について検討した. 添加物は液相の生成 する温度にそれほど影響がなく，焼成段階で $\mathrm{ZnO}$ には 固溶せず液相中に存在する成分として $\mathrm{CaO}, \mathrm{SrO}$, $\mathrm{BaO}, \mathrm{SiO}_{2}$ を, $\mathrm{ZnO}$ に固溶する成分として $\mathrm{CoO}$ と $\mathrm{MnO}$ の 6 種類を選んだ。

\section{2. 実験方法}

\section{1 試料の調製}

出発原料は正同化学社製 $\mathrm{ZnO}$ (純度 $99.99 \%$, 粒径 $0.3 \sim 0.4 \mu \mathrm{m}$ ) 及び三津和化学社製 $\mathrm{NbCl}_{5}$ (純度 $99.6 \%$ ) である.第 3 成分として選んだ 6 種の添加物はそれぞれ， $\mathrm{Ca}\left(\mathrm{NO}_{3}\right)_{2} \cdot 4 \mathrm{H}_{2} \mathrm{O}, \mathrm{Ba}\left(\mathrm{NO}_{3}\right)_{2}, \mathrm{Sr}\left(\mathrm{NO}_{3}\right)_{2}, \mathrm{Co}\left(\mathrm{NO}_{3}\right)_{2} \cdot 6$ $\mathrm{H}_{2} \mathrm{O}, \mathrm{Mn}\left(\mathrm{NO}_{3}\right)_{2} \cdot 6 \mathrm{H}_{2} \mathrm{O}, \mathrm{Si}\left(\mathrm{OCH}_{3}\right)_{4}$ を溶液の形で添加 した。まず所定量の $\mathrm{NbCl}_{5}$ エ夕ノール溶液と，第 3 添 加化合物のエ夕ノール溶液又は水溶液をビーカーに亡 り，更にエタノールを加えてテフロン製スターラーでか くはんしながら $\mathrm{ZnO}$ 粉末を加え, 混合と加水分解, 更

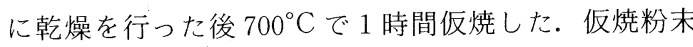
は最終的に $1000 \mathrm{~kg} / \mathrm{cm}^{2}$ の静水圧で, 直径約 $10 \mathrm{~mm}$, 厚さ 2 - 3 mm の円板状に成形し, 液相の生成する温度 範囲内である $1305^{\circ} \mathrm{C}$ で 1 時間空気中で焼成を行った後 炉冷した。昇温速度は $6{ }^{\circ} \mathrm{C} / \mathrm{min}$ である。添加量につい ては, $\mathrm{Nb}_{2} \mathrm{O}_{5}$ を $1 \mathrm{~mol} \%$ に固定し, 第 3 成分は酸化物と して $0.1 \mathrm{~mol}$ 及び $0.5 \mathrm{~mol} \%$ とした。

\section{2 実験方法}

焼成体の室温における電圧-電流特性は, 試料の両面 を約 $2 \mathrm{~mm}$ に研磨し, 電極としてオーミック接触が得ら れる In-Hgアマルガム ${ }^{11}$ を塗布後銅板を圧着し, 直流
定電圧電源（横河電機社製，直流校正装置 Type 2563） とデジタルナノアンメーター（タケダ理研製，TR 8642） を用いて直流二端子法で測定した．測定は印加電圧が $10^{-5} \mathrm{~V}$ 付近より行ったが, その上限は電圧の印加によっ て試料が加熱され，電流值が変動するまで行った。試料 の比抵抗值は電圧-電流特性のオーミック領域より求め た。バリス夕一特性の現れた試料の非直線性指数 $\alpha$ は 次式の $I_{2}=10 \mathrm{~mA}, I_{1}=1 \mathrm{~mA}$ のきの值として求め, バ リスタ一電圧は試料に $1 \mathrm{~mA} / \mathrm{cm}^{2}$ の電流が流れたときの 単位長さ当たりの電圧 $(\mathrm{V} / \mathrm{mm})$ で表した

$$
\alpha \simeq \frac{\log I_{2}-\log I_{1}}{\log V_{2}-\log V_{1}}
$$

焼成体の組織は研磨面を希塩酸 $(0.04 \%)$ で約 20 秒間 エッチングし，走査型電子顕微鏡（日立製作所製, HSM-2 型）により観察した。第 3 成分の分布状態につ いてはX線マイクロアナライザー（日立製作所製， X-560+Kevex EDX) により調べた。粒界相（3 $\left.\mathrm{ZnO} \cdot \mathrm{Nb}_{2} \mathrm{O}_{5}\right)$ の格子定数は粉末 $\mathrm{X}$ 線回折法により, 金 属シリコンを内部標準として測定した。測定には回転対 陰極型（理学電機社製, RU-200）で黒鉛分光結晶で単 色化した $\mathrm{CuK} \alpha$ 線を用い, $40 \mathrm{kV}, 100 \mathrm{~mA}$ ，スリット 系 $1^{\circ}-1^{\circ}-0.15-0.3$ の条件で行った。また $\mathrm{Mn} の \mathrm{ZnO}$ 中 への固溶量の測定には, 粒界相が塩酸に不溶であること を利用して ${ }^{(0)}$, 焼成体を約 $18 \%$ の塩酸で処理して $\mathrm{ZnO}$ 粒子を溶解させ, 得られた溶液について $\mathrm{MnO}$ の原子吸 光分析を行った (島津製作所製, MAF-1 形).

\section{3. 実験結果と考察}

\section{1 焼成体の比抵抗と組織}

$1 \mathrm{~mol} \%$ の $\mathrm{Nb}_{2} \mathrm{O}_{5}$ と $0.5 \mathrm{~mol} \%$ の第 3 成分を含む $\mathrm{ZnO}$ 焼成体の電圧-電流特性の一例を図1に示す. 1 $\mathrm{mol} \%$ の $\mathrm{Nb}_{2} \mathrm{O}_{5}$ と $0.5 \mathrm{~mol} \%$ の $\mathrm{MnO}$ を含む焼成体は,

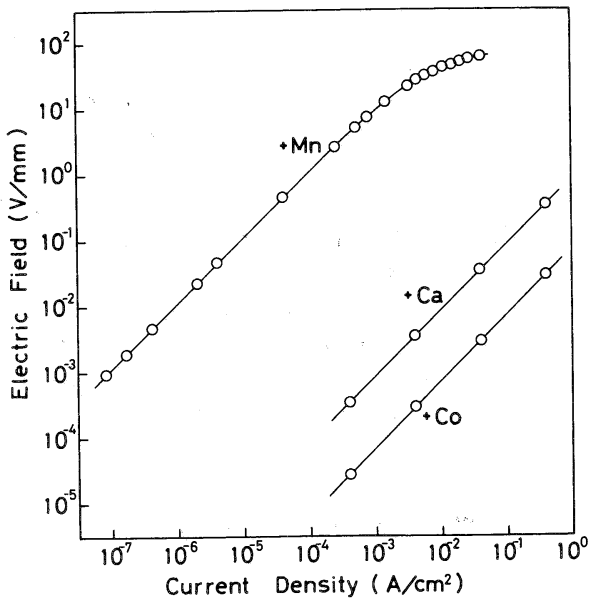

Fig. 1. $\quad V-I$ characteristics of $\mathrm{ZnO}-\mathrm{Nb}_{2} \mathrm{O}_{5}(1 \mathrm{~mol} \%)$ specimens containing $0.5 \mathrm{~mol} \%$ additives. 


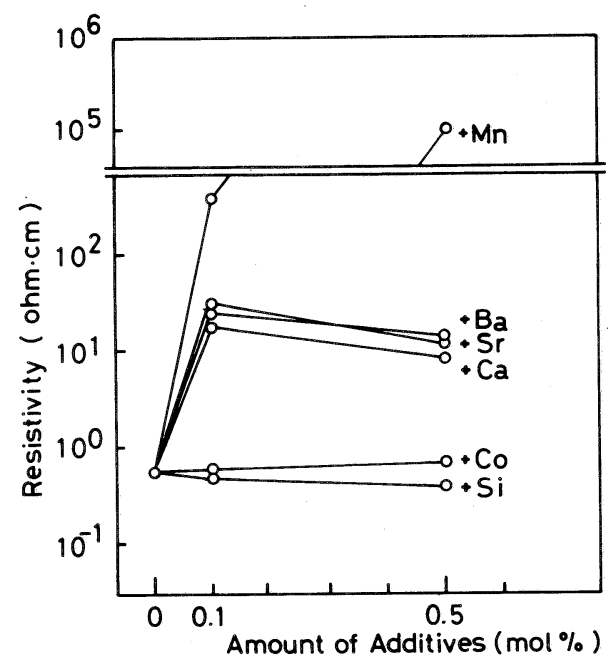

Fig. 2. Effect of additives on room-temperature electrical resistivity of the fired $\mathrm{ZnO}$ specimens containing $1.0 \mathrm{~mol} \% \mathrm{Nb}_{2} \mathrm{O}_{5}$.

低電圧領域ではオーミックであるが，高電圧領域では オーミックからずれてバリスター性が現れた。それ以外 の焼成体はいずれも測定範囲内ではオーミックであっ た.オーミック領域から求めた比抵抗值を図 2 に示し, 第 3 成分の種類とその添加量による影響を調べた. 1 $\mathrm{mol} \%$ の $\mathrm{Nb}_{2} \mathrm{O}_{5}$ を含むだけの試験片の比抵抗值は約 0.6 $\Omega \cdot \mathrm{cm}$ である、第 3 成分を加えた試験片では, $\mathrm{SiO}_{2}$ の 添加によってわずかではあるが減少する傾向があり, $\mathrm{CoO}$ を添加したものでは比抵抗值はほとんど変化しな い. $\mathrm{CaO}, \mathrm{SrO}, \mathrm{BaO}$ を添加した試験片ではどれも同じ ような傾向を示し， $0.1 \mathrm{~mol} \%$ の添加で比抵抗值は約一 けた半増加するが, $0.5 \mathrm{~mol} \%$ 添加した場合は逆に若干 減少する傾向にある.これらに対して $\mathrm{MnO}$ を添加した 試験片では $\mathrm{MnO}$ の添加に伴って比抵抗值は急激に増加 し, $0.5 \mathrm{~mol} \%$ の増加で $1.1 \times 10^{5} \Omega \cdot \mathrm{cm}$ となった. また この $0.5 \mathrm{~mol} \%$ の $\mathrm{MnO}$ を添加した試験片は, 図 1 に示 したようにバリスター特性が認められたが，このときの $\alpha$ 值は約 3 ,バリス夕一電圧 $\left(\mathrm{V}_{1 \mathrm{~mA}}\right)$ は約 $8.8 \mathrm{~V}$ であった。

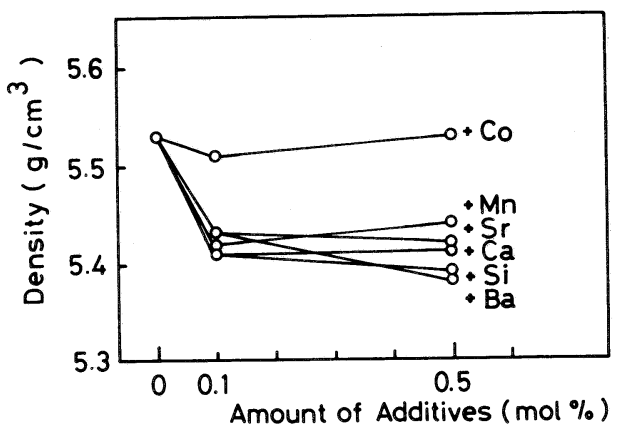

Fig. 3. Effect of additives on fired density of the $\mathrm{ZnO}$ specimens containing $1.0 \mathrm{~mol} \% \mathrm{Nb}_{2} \mathrm{O}_{5}$.
Table 1. Constituent crystals of fired $\mathrm{ZnO}-\mathrm{Nb}_{2} \mathrm{O}_{5}$ (1 mol \%) specimens containing various additives.

\begin{tabular}{|c|c|c|}
\hline \multirow[b]{2}{*}{ Aadditive } & \multicolumn{2}{|c|}{ Content } \\
\hline & $0.1 \mathrm{~mol} 8 \mathrm{8}$ & $0.5 \mathrm{~mol} \frac{\mathrm{\circ}}{\mathrm{r}}$ \\
\hline $\mathrm{CaO}$ & $\mathrm{znO}, \quad 3 \mathrm{ZnO} \cdot \mathrm{Nb}_{2} \mathrm{O}_{5}$ & $\begin{array}{c}\mathrm{ZnO}, 3 \mathrm{ZnO} \cdot \mathrm{Nb}_{2} \mathrm{O}_{5} \\
\mathrm{CaO} \cdot \mathrm{Nb}_{2} \mathrm{O}_{5}\end{array}$ \\
\hline Sro & $\begin{array}{c}\mathrm{znO}, \quad 3 \mathrm{ZnO} \cdot \mathrm{Nb}_{2} \mathrm{O}_{5} \\
\quad \mathrm{SrO} \cdot \mathrm{Nb}_{2} \mathrm{O}_{5}\end{array}$ & $\begin{array}{c}\mathrm{ZnO}, \quad 3 \mathrm{ZnO} \cdot \mathrm{Nb}_{2} \mathrm{O}_{5} \\
\mathrm{SrO} \cdot \mathrm{Nb}_{2} \mathrm{O}_{5}\end{array}$ \\
\hline $\mathrm{BaO}$ & $\begin{array}{c}\mathrm{ZnO}, 3 \mathrm{zno} \cdot \mathrm{Nb}_{2} \mathrm{O}_{5} \\
\text { un-identified phase }\end{array}$ & $\begin{array}{c}\mathrm{ZnO}, \quad 3 \mathrm{ZnO} \cdot \mathrm{Nb}_{2} \mathrm{O}_{5} \\
\text { un-identified phase }\end{array}$ \\
\hline $\mathrm{SiO}_{2}$ & $\begin{array}{c}\mathrm{zno}, 3 \mathrm{ZnO} \cdot \mathrm{Nb}_{2} \mathrm{O}_{5} \\
2 \mathrm{ZnO} \cdot \mathrm{SiO}_{2}\end{array}$ & $\begin{array}{c}\mathrm{ZnO}, \quad 3 \mathrm{ZnO} \cdot \mathrm{Nb}_{2} \mathrm{O}_{5} \\
2 \mathrm{znO} \cdot \mathrm{SiO}_{2}\end{array}$ \\
\hline $\mathrm{CoO}$ & $\mathrm{ZnO}, 3 \mathrm{ZnO} \cdot \mathrm{Nb}_{2} \mathrm{O}_{5}$ & $\mathrm{znO}, 3 \mathrm{ZnO} \cdot \mathrm{Nb}_{2} \mathrm{O}_{5}$ \\
\hline $\mathrm{MnO}$ & $\mathrm{ZnO}, 3 \mathrm{znO} \cdot \mathrm{Nb}_{2} \mathrm{O}_{5}$ & $\mathrm{ZnO}, \quad 3 \mathrm{znO} \cdot \mathrm{Nb}_{2} \mathrm{O}_{5}$ \\
\hline
\end{tabular}

図 3 に焼成体かさ密度を示した。第 3 成分無添加の試 験片では $5.52 \mathrm{~g} / \mathrm{cm}^{3}$ (相対密度 $97.0 \%$ ) であるが，第 3 成分を添加すると $\mathrm{CoO}$ の場合はほとんど変化せず, そのほかの成分を添加した場合にはいずれもかさ密度は $5.4 \mathrm{~g} / \mathrm{cm}^{3}$ 前後に減少する. 第 3 成分を添加した場合の 試験片の真密度の值は明らかではないが，第 3 成分無添 加試験片の值を使って相対密度を計算すると, $\mathrm{CoO}$ を 添加した試験片が $97 \%$ ，そのほかの成分を添加したも のでは 94.7〜95.8\%の間に入っており，実際の相対密 度もほぼこれに近い值と考えられる。

焼成体の構成結晶相は表 1 に示すように, $\mathrm{CaO}$ を $0.1 \mathrm{~mol} \%$ 添加した試験片では $\mathrm{ZnO}$ と $3 \mathrm{ZnO} \cdot \mathrm{Nb}_{2} \mathrm{O}_{5}$ で あるが，0.5 mol\% 添加した試験片ではそれらのほかに $\mathrm{CaO} \cdot \mathrm{Nb}_{2} \mathrm{O}_{5}$ が認められた. $\mathrm{SiO}_{2}$ と $\mathrm{SrO}$ を添加した試 験片では, $\mathrm{ZnO}$ と $3 \mathrm{ZnO} \cdot \mathrm{Nb}_{2} \mathrm{O}_{5}$ のほかにそれぞれ，2 $\mathrm{ZnO} \cdot \mathrm{SiO}_{2}, \mathrm{SrO} \cdot \mathrm{Nb}_{2} \mathrm{O}_{5}$ が認められた. $\mathrm{CoO}$ と $\mathrm{MnO}$ を 添加した試験片では, 添加量が $0.5 \mathrm{~mol} \%$ のものでも $\mathrm{ZnO}$ と $3 \mathrm{ZnO} ・ \mathrm{Nb}_{2} \mathrm{O}_{5}$ のみであり， $\mathrm{BaO}$ を添加したもの では $\mathrm{ZnO}$ と $3 \mathrm{ZnO} \cdot \mathrm{Nb}_{2} \mathrm{O}_{5}$ のほかに未同定相の回折線が 認められた。この結果から $\mathrm{CaO}, \mathrm{CoO}, \mathrm{MnO}$ は $\mathrm{ZnO}$ 又は $3 \mathrm{ZnO} \cdot \mathrm{Nb}_{2} \mathrm{O}_{5}$ への固溶の可能性が考えられる.こ れについては次節で更に検討する.

粒界相の $\mathrm{ZnO}$ 粒子に対するぬれ性を研磨エッチング 面について観察した. 第 3 成分の添加量が $0.1 \mathrm{~mol} \%$ の 場合の結果の一例を図 4 に示す. 第 3 成分を添加してい ない試験片では, 粒界相は $\mathrm{ZnO}$ 粒子に対するぬれ性が あまり良くなく, $\mathrm{ZnO}$ 粒界に比較的丸い形で存在して いる.これに対して, $\mathrm{CaO}, \mathrm{SrO}, \mathrm{BaO}, \mathrm{SiO}_{2}$ をそれぞ れ $0.1 \mathrm{~mol} \%$ 添加した試験片では，粒界相は $\mathrm{ZnO}$ 粒子 間に入り込んでおり，ぬれ性は著しく良くなっている。 しかしまだ完全には $\mathrm{ZnO}$ 粒界に浸透しきっておらず， 粒界相の先端部の一部は丸くなっている様子が観察され る. $\mathrm{MnO}$ を $0.1 \mathrm{~mol} \%$ 添加した試験片では, 第 3 成分 無添加試験片と比較すると姓は若干良いようであ 

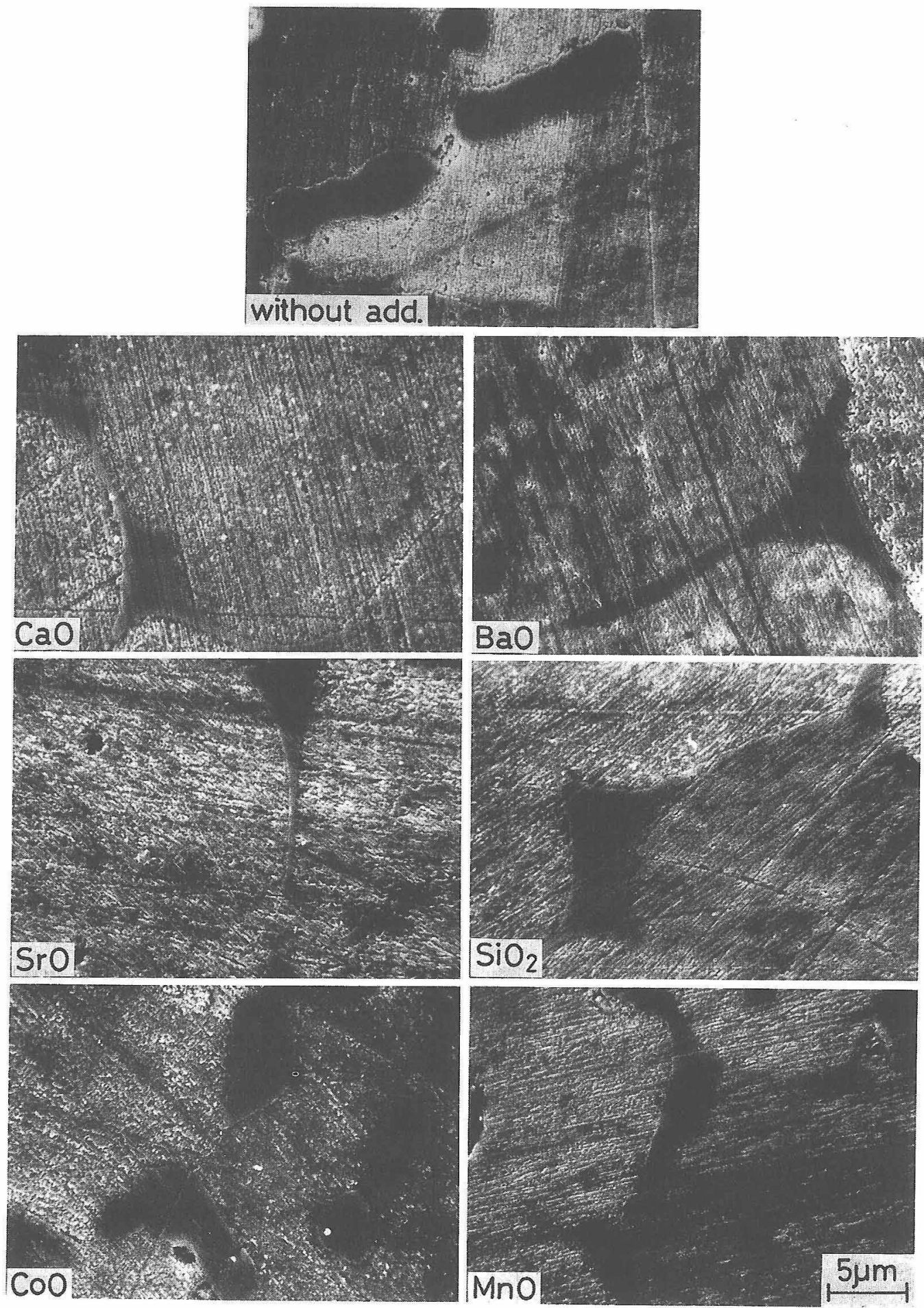

Fig. 4. Scanning electron micrographs of the polished and etched surface of $\mathrm{ZnO}_{\mathrm{nO}} \mathrm{Nb}_{2} \mathrm{O}_{5}(1.0 \mathrm{~mol} \%)$ specimens containing $0.1 \mathrm{~mol} \%$ of various additives.

る. $\mathrm{CoO}$ を $0.1 \mathrm{~mol} \%$ 添加したものでは，第 3 成分無 添加試験片とほぼ同じような組織をしており，ZnO 粒 子に対するぬれ性の改善は認められない，第 3 成分の添
加量が $0.5 \mathrm{~mol} \%$ の場合についても $0.1 \mathrm{~mol} \%$ の場合上 同㥞の傾向が見られ，添加量の増加による組織の大きな 変化は認められなかった。したがって, $\mathrm{CaO}, \mathrm{SrO}$, 
$\mathrm{BaO}, \mathrm{SiO}_{2}$ の添加は粒界相の性質を变化させ, $\mathrm{ZnO}$ 粒 子へのぬ性を著しく良くすることが分った。

\section{2 第 3 成分の分布状態}

烧成体の微構造が第 3 涯加成分の種頑によって相当な 違いが認められたので，焼成体中での第 3 成分の分布を X 線マイクロアナライザーによって調べた。 また添加 成分のうち, $\mathrm{CaO}, \mathrm{MnO}, \mathrm{CoO}$ は $\mathrm{ZnO}$ 又は $3 \mathrm{ZnO}$. $\mathrm{Nb}_{2} \mathrm{O}_{5}$ (粒界相) に固溶の可能性が予想されたので, そ れらを添加した試験片について $\mathrm{ZnO}$ と $3 \mathrm{ZnO} \cdot \mathrm{Nb}_{2} \mathrm{O}_{5}$ の 格子定数を測定した。

第 3 成分ををれぞれ $0.5 \mathrm{~mol} \%$ 添加した試験片につい て、X線マイクロアナライザーにより研磨面の面分析, 線分析を行った結果の一例を図 5 から図 9 に示す。 $\mathrm{CaO}$ を添加した試験片では図 5 にみられるように，2 次電子線でやや白く観察される部分が粒界相に相当し, この部分に $\mathrm{Nb}$ 原子と $\mathrm{Ca}$ 原子が強く浱縮していること
が分る. またエネルギ一分散型 X 線マイクロアナライ ザー (EDX) に上る点分析の結果，ZnO 粒内には $\mathrm{Nb}$ 原子及び $\mathrm{Ca}$ 原子は検出されなかった。そのほかの試験 片についても $\mathrm{Nb}$ 原子は粒界相にのみ濃縮し， $\mathrm{ZnO}$ 粒 子内では検出できなかった，SrO 及び $\mathrm{BaO}$ を添加した 試験片では， $\mathrm{CaO}$ を添加したものと同様，粒界相中に $\mathrm{Sr}$ 原子、 $\mathrm{Ba}$ 原子が強く濃縮しており，またこれらの原 子は $\mathrm{ZnO}$ 粒内には検出されなかった。図6, 図7は $\mathrm{CoO}$ と $\mathrm{MnO}$ をそれぞれ $0.5 \mathrm{~mol} \%$ 添加した試験片の 結果を示したものであるが，CoO を添加したものでは Co 原子の濃縮した部分は認められず， $\mathrm{ZnO}$ 粒内及び粒 界相の両方に Co 原子の存在が確認された. MnO を添 加した試験片の場合も $\mathrm{ZnO}$ 粒内と粒界相の両方に $\mathrm{Mn}$ 原子は検出されるが，線分析の結果から粒界相中に濃縮 していることが分かった. $\mathrm{MnO}$ を $0.5 \mathrm{~mol} \%$ 添加した 試験片にはバリスタ一特性が認められているので，粒界
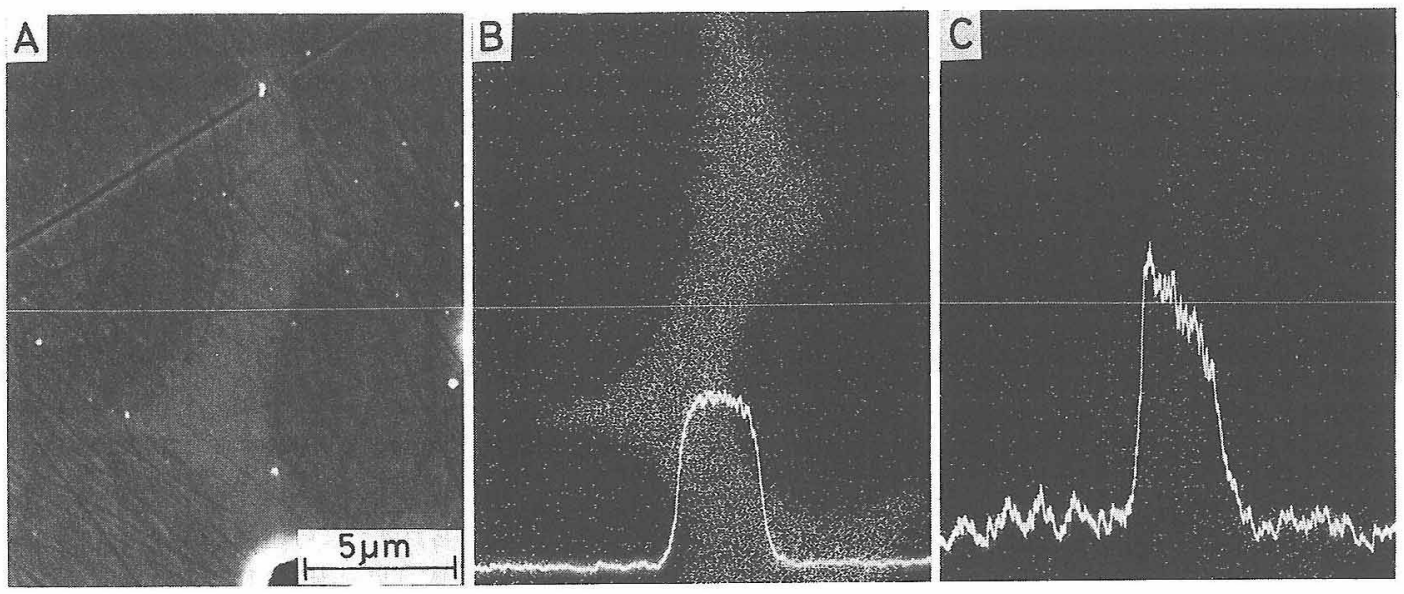

Fig. 5. Electron micrographs of the fired $\mathrm{ZnO}$ specimen containing 1.0 mol\% $\mathrm{Nb}_{2} \mathrm{O}_{5}$ and $0.5 \mathrm{~mol} \% \mathrm{CaO}$. A : Secondary electron image,

$\mathrm{B}$ : Characteristic X-ray image and line profile of $\mathrm{Nb}$, $\mathrm{C}$ : Characteristic $\mathrm{X}$-ray image and line profile of $\mathrm{Ca}$

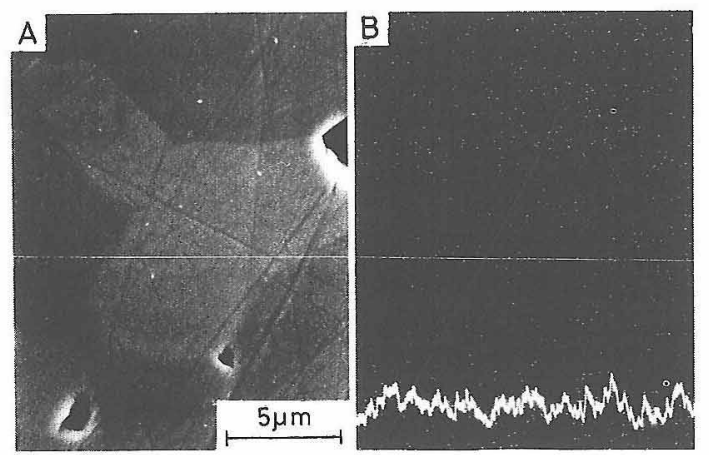

Fig. 6. Electron micrographs of the fired $\mathrm{ZnO}$ specimen containing $1.0 \mathrm{~mol} \% \mathrm{Nb}_{2} \mathrm{O}_{5}$ and $0.5 \mathrm{~mol} \%$ $\mathrm{CoO}$.

A : Secondary electron image,

$\mathrm{B}:$ Characteristic X-ray image and line profile of Co
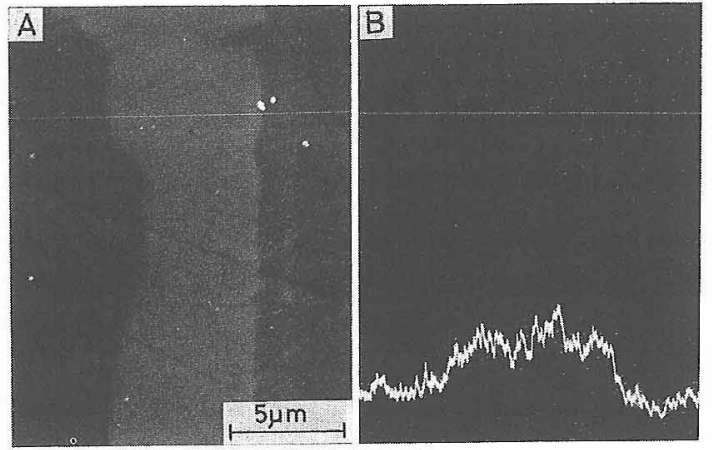

Fig. 7. Electron micrographs of the fired $\mathrm{ZnO}$ specimen containing $1.0 \mathrm{~mol} \% \quad \mathrm{Nb}_{2} \mathrm{O}_{5}$ and $0.5 \mathrm{~mol} \%$ $\mathrm{MnO}$.

A : Secondary electron image,

$\mathrm{B}$ : Characteristic X-ray image and line profile of $\mathrm{Mn}$ 
相の存在しない $\mathrm{ZnO}$ 粒界の $\mathrm{Mn}$ 原子の線分析を行っ た。結果は図 8 に示したようにこの测定範囲内では $\mathrm{Mn}$ 原子が粒界に浱縮している傾向は認められなかった。更 に $\mathrm{ZnO}$ 粒子内部乞粒界相に近い部分の $\mathrm{Mn}$ 濃度を EDXにより比較したが，有意義な差は認められなかっ た. 図 9 は $\mathrm{SiO}_{2}$ を添加した結果を示したが，2次電子 線像において粒界相中に気孔よは異なるが黒色に観察さ れる部分が存在し，その部分にSi 原子の濃縮が認めら れた。更に EDXの測定結果から，この部分には Nb 原 子は存在せず $\mathrm{Zn}$ 原子と $\mathrm{Si}$ 原子のみが検出さ扎たこと から，2次電子線像で黒色に観察さ扎た部分は 2 $\mathrm{ZnO} \cdot \mathrm{SiO}_{2}$ であると考えられる。

$\mathrm{CaO}, \mathrm{CoO}, \mathrm{MnO}$ を添加した試験片の $\mathrm{ZnO}$ の格子定

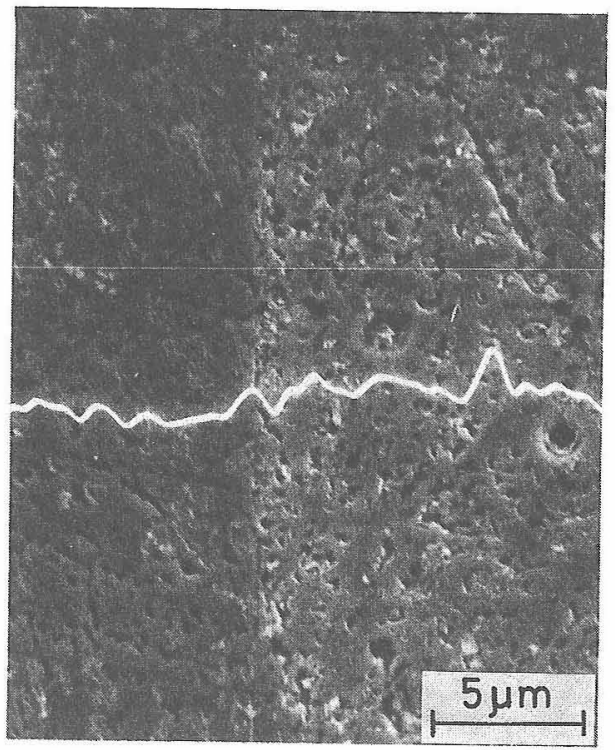

Fig. 8. Secondary electron image and $\mathrm{Mn}$ characteristic X-ray line profile of the $\mathrm{ZnO}$ grain boundary in the $\mathrm{ZnO}$ specimen containing $1.0 \mathrm{~mol} \%$ $\mathrm{Nb}_{2} \mathrm{O}_{5}$ and $0.5 \mathrm{~mol} \% \mathrm{MnO}$.

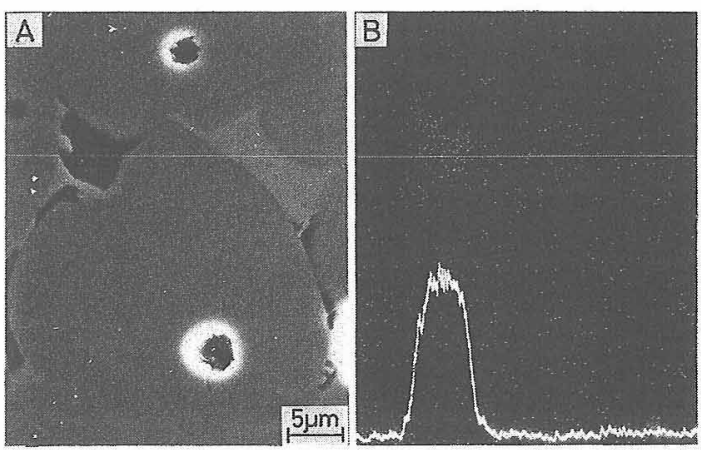

Fig. 9. Electron micrographs of the fired $\mathrm{ZnO}$ specimen containing $1.0 \mathrm{~mol} \% \quad \mathrm{Nb}_{2} \mathrm{O}_{5}$ and $0.5 \mathrm{~mol} \%$ $\mathrm{SiO}_{2}$.

A : Secondary electron image,

B : Characteristic X-ray image and line profile of Si
数は, 光学用不英を内部標準として ZnO $の(104) と(300)$ の回折線より求めたが，結果はいずれも $a_{0}=3.249 \AA$, $c_{0}=5.205 \AA$ を示し, $\mathrm{Nb}_{2} \mathrm{O}_{5}$ も含まない $\mathrm{ZnO}$ 単味の格 子定数と有意義な差は認められなかった。 Sōmiyaら は ${ }^{121} \mathrm{ZnO} へ の \mathrm{Mn}_{2} \mathrm{O}_{3}$ の固溶量に対する格子定数变化 は， $a_{0}, c_{0}$ ともに $\mathrm{Mn}_{2} \mathrm{O}_{3} 5 \mathrm{wt} \%(\mathrm{MnO}$ で $4.9 \mathrm{~mol} \%)$ で約 $0.01 \AA$ であること走しているので, $\mathrm{MnO}$ が 0.5 $\mathrm{mol} \%$ 以下の固溶量では格子定数変化の検出は困難であ ると思われる． $\mathrm{CoO} の$ 添加の場合も $\mathrm{Co}^{2+}$ のイオン半径 が $\mathrm{Zn}^{2+}$ に近いので格子定数変化の検出は更に困難であ ると考えられる。 $3 \mathrm{ZnO} \cdot \mathrm{Nb}_{2} \mathrm{O}_{5}$ の格子定数については， その結晶系に斜方晶 ${ }^{131}$ 之単斜晶 ${ }^{14}$ の二つが報告されてい るが，単斜晶の場合も $\beta=90.0^{\circ}$ 之報告されているので， ここでは斜方晶を採用して格子定数を求めた。 $\mathrm{CaO}$ を 添加した場合は (251)，(171)，(111）の回折線，CoO と $\mathrm{MnO}$ を添加した場合は (251)，(171)，(022）の回 折線の $d$ 值より計算した。結果は図 10に示すように, $\mathrm{CoO}$ を添加した試験片では無添加のものとはとんど差 は認められない，MnO を添加した場合は $0.1 \mathrm{~mol} \%$ の 添加量でほとんど変化はみられないが，0.5 mol\%の添 加で $a$ 軸， $b$ 軸， $c$ 軸のいずれもわずかではあるが大 きくなっている， $\mathrm{CaO}$ を添加した試験片では $b$ 軸はほ とんど変化しないが $a$ 軸と $c$ 軸は $\mathrm{CaO}$ の添加量ととも に大きくなることが分った.したがって $\mathrm{CaO} と \mathrm{MnO}$ は添加したうちの一部は $3 \mathrm{ZnO} \cdot \mathrm{Nb}_{2} \mathrm{O}_{5}$ 相に固溶してい ると考えられる。CoOを添加した試験片では，X線マ イクロアナライザーの测定結果からCo 原子が粒界相中 に存在することは確認されたが， $3 \mathrm{ZnO} \cdot \mathrm{Nb}_{2} \mathrm{O}_{5}$ 相の格 子定数变化は認められず，この結果からだけでは固溶の

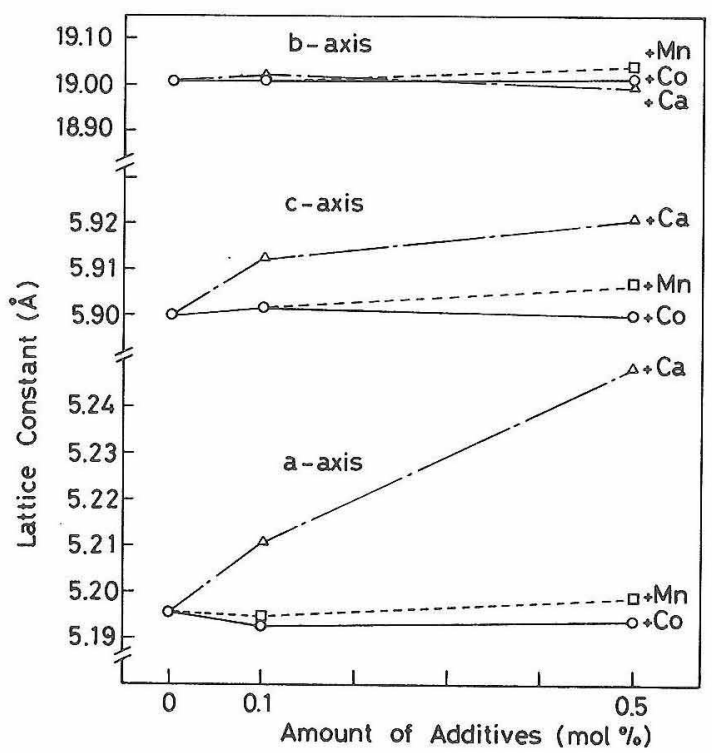

Fig. 10. Effect of the amount of additives on the lattice constant of $3 \mathrm{ZnO} \cdot \mathrm{Nb}_{2} \mathrm{O}_{5}$ phase. 
有無は判定できなかった。

$\mathrm{CaO}, \mathrm{SrO}, \mathrm{BaO}$ の添加は粒界相の $\mathrm{ZnO}$ 粒子に対す るぬ栍を著しく改善し，そしてそれらを $0.1 \mathrm{~mol} \%$ 添 加することによって比抵抗值は第 3 成分無添加試験片の 値の一けた以上に増加した。この比抵抗值の増加は, 図 3 に見られるように焼成体かさ密度の減少による影響も 考えられるが，その減少は相対密度が $97 \%$ から $95 \%$ 前 後とわずかであるためこの効果は少なく，ぬれ性の影響 の方が大きいと思われる。すなわち，高抵抗である粒界 相 ${ }^{10)}$ の $\mathrm{ZnO}$ 粒子に対するぬれ性が良くなって $\mathrm{ZnO}$ 粒界 に浸透し, $\mathrm{ZnO}$ 粒子同士の直接の接触を減少させて比 抵抗値を増加させたものと考えられる.

$\mathrm{SiO}_{2}$ の添加も粒界相の $\mathrm{ZnO}$ に対するぬれ性を良くし たが，この場合の比抵抗值は逆に第 3 成分無添加試料よ りも低くなる傾向があった。この原因については不明な 点が多いが, $\mathrm{SiO}_{2}$ の添加の場合は $2 \mathrm{ZnO} \cdot \mathrm{SiO}_{2}$ 相が粒 界相の一部として析出し, 粒界相の組織が $\mathrm{CaO}, \mathrm{SrO}$, $\mathrm{BaO}$ を添加した場合と異なっていることに関係がある 亡思われる.

\section{$3.3 \mathrm{ZnO}-\mathrm{Nb}_{2} \mathrm{O}_{5}-\mathrm{MnO}$ 系における $\mathrm{Nb}_{2} \mathrm{O}_{5}$ 添加量 の影響}

第 3 成分として $\mathrm{MnO}$ を添加した場合は，粒界相のぬ れ性はそれほど変化しないが, 比抵抗值は添加量ととも に著しく増加し， $0.5 \mathrm{~mol} \%$ 添加した試験片においては バリス夕一特性が認められた。これらの関係を更に検討 するために， $\mathrm{ZnO}-\mathrm{Nb}_{2} \mathrm{O}_{5}-\mathrm{MnO}$ 系において $\mathrm{MnO}$ 量を $0.5 \mathrm{~mol} \%$ に固定して， $\mathrm{Nb}_{2} \mathrm{O}_{5}$ の添加量を0 1 mol\% の範囲で変化させ, 得られた焼成体の比抵抗, かさ密度, 組織等を調べた。

$1305^{\circ} \mathrm{C}$ 焼成体の $\mathrm{Nb}_{2} \mathrm{O}_{5}$ 添加量に対する比抵抗值を図 11 に, かさ密度の值を図 12 に示す。比抵抗值は, $\mathrm{Nb}_{2} \mathrm{O}_{5}$ の添加量が 0 の場合は $5.4 \times 10^{4} \Omega \cdot \mathrm{cm}$ と大きな 值であるが，これに $0.1 \mathrm{~mol} \%$ の $\mathrm{Nb}_{2} \mathrm{O}_{5}$ を添加すると 急激に減少し $8.3 \Omega \cdot \mathrm{cm}$ になる。 それよりも $\mathrm{Nb}_{2} \mathrm{O}_{5}$ の 量が増加すると比抵抗值は徐々に増加し， $1 \mathrm{~mol} \%$ の添 加で再び急激に増加して $1.1 \times 10^{5} \Omega \cdot \mathrm{cm}$ と高い比抵抗 值を示す。この $1 \mathrm{~mol} \% の \mathrm{Nb}_{2} \mathrm{O}_{5}$ を添加した試験片は 図 1 の $\mathrm{MnO}$ を添加したものと同じ試験片であって, こ れにはバリスタ一特性が見られたが， $\mathrm{Nb}_{2} \mathrm{O}_{5}$ を添加しな い試験片，すなわち $\mathrm{MnO}$ を添加しただけのものにも若 干のバリスタ一特性が認められ，このときの $d$ 值は 1.7 であった。

かさ密度は $\mathrm{ZnO}$ に $\mathrm{MnO}$ を $0.5 \mathrm{~mol} \%$ 添加しただけ のものでは $5.14 \mathrm{~g} / \mathrm{cm}^{3}$ であるが， $\mathrm{Nb}_{2} \mathrm{O}_{5}$ を添加するこ とによって増加し， $0.1 \sim 0.4 \mathrm{~mol} \%$ のものて 5.52 $\mathrm{g} / \mathrm{cm}^{3}, 1 \mathrm{~mol} \%$ の添加でやや減少して $5.44 \mathrm{~g} / \mathrm{cm}^{3}$ の值 となる。

焼成体の研磨エッチング面の観察結果の一例を図 13

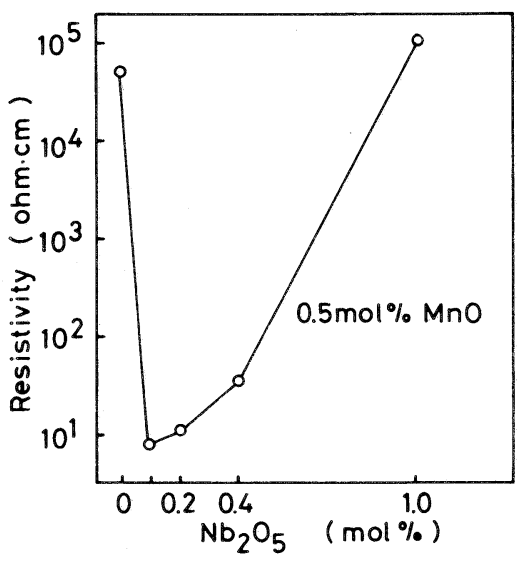

Fig. 11. Effect of $\mathrm{Nb}_{2} \mathrm{O}_{5}$ content on room-temperature resistivity of the fired $\mathrm{ZnO}$ specimens containing 0.5 mol \% $\mathrm{MnO}$.

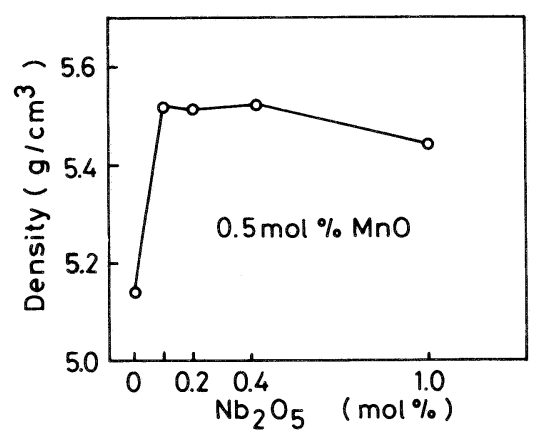

Fig. 12. Effect of $\mathrm{Nb}_{2} \mathrm{O}_{5}$ content on fired density of the $\mathrm{ZnO}$ specimens containing $0.5 \mathrm{~mol} \% \mathrm{MnO}$.

に示す. ZnOに $0.5 \mathrm{~mol} \%$ の $\mathrm{MnO}$ を添加しただけの試 験片では，粒径は $10 \mu \mathrm{m}$ 前後のものが多く, 液相の生 成がなくて粒界相は見られない。また粒界には $5 \mu \mathrm{m}$ 以 下の気孔が数多く試料全体に均一に分散して認められ た. $\mathrm{Nb}_{2} \mathrm{O}_{5}$ を添加した試験片はいずれも液相焼結によっ てち密化し， ZnOの粒径は50〜60 $\mu \mathrm{m}$ と大きくなって おり， $3 \mathrm{ZnO} \cdot \mathrm{Nb}_{2} \mathrm{O}_{5}$ からなる粒界相が認められる.こ の粒界相は $\mathrm{Nb}_{2} \mathrm{O}_{5}$ の添加量が増すに従い増加するが, 粒界相の $\mathrm{ZnO}$ 粒子に対するぬれ性はあまり良くない。

前節のX 線マイクロアナライザーの結果は $\mathrm{MnO}$ が $\mathrm{ZnO}$ 粒子と粒界相の両方に存在していることを示した が, $\mathrm{Nb}_{2} \mathrm{O}_{5}$ の添加量の変化によって $\mathrm{MnO}$ の存在量がよ゙ のように変わるかを調べるため, ZnOを塩酸で溶解さ せそれに固溶している $\mathrm{MnO}$ 量を原子吸光分析で測定し た。粒界相中の $\mathrm{MnO}$ 濃度は, $\mathrm{ZnO}$ 粒子中に含まれて いる $\mathrm{MnO}$ 量を除いた量と粒界相の体積分率とから求め た。体積分率は次のように計算で求めた。各焼成体の EDX 測定において，ZnO 粒内に $\mathrm{Nb}$ 原子が検出されな いことから，添加した $\mathrm{Nb}_{2} \mathrm{O}_{5}$ はすべて $\mathrm{ZnO}$ と反応して $3 \mathrm{ZnO} \cdot \mathrm{Nb}_{2} \mathrm{O}_{5}$ に変わって粒界相を形成したと考えられ 

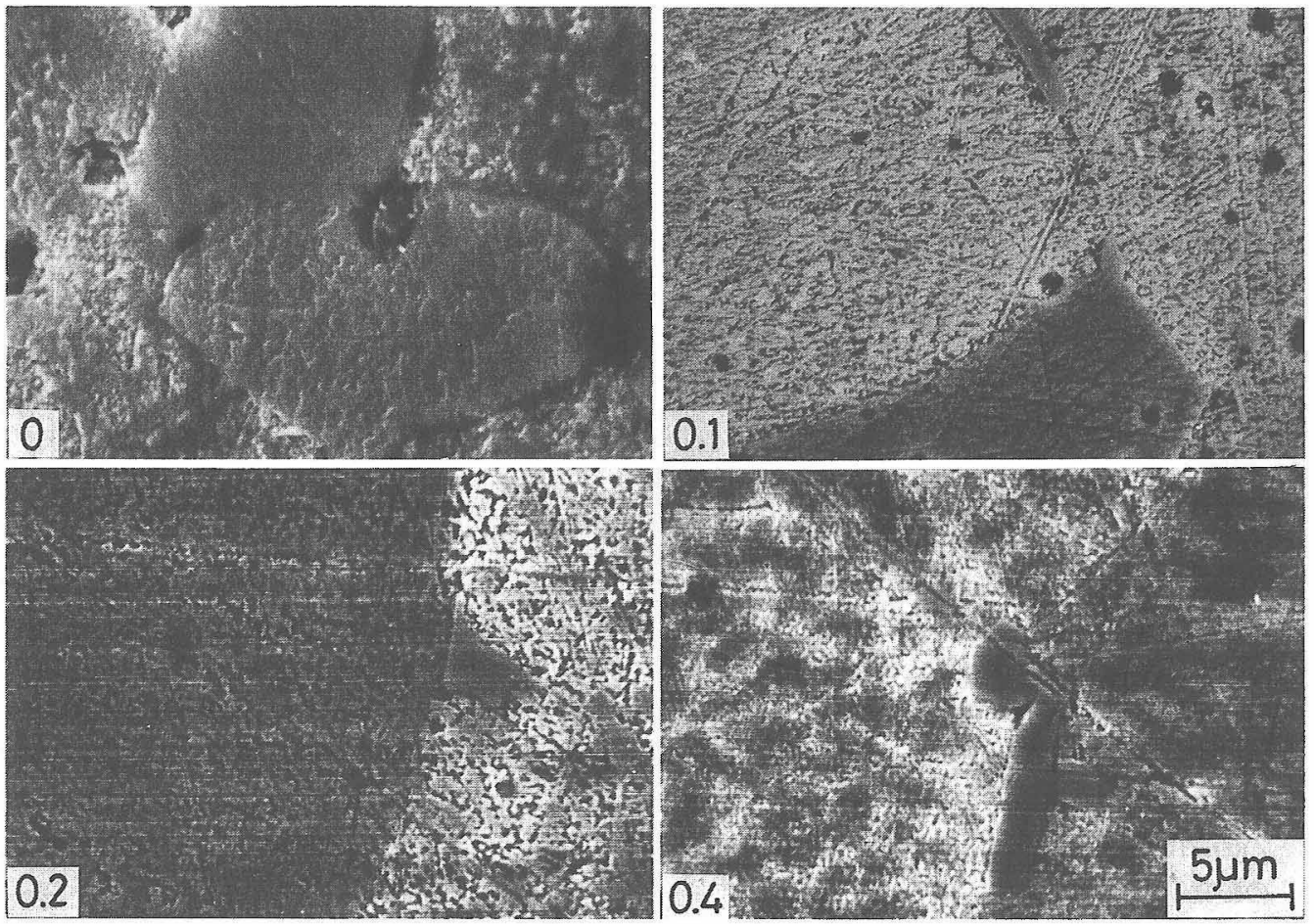

Fig. 13. Scanning electron micrographs of the polished and etched surfaec of $\mathrm{ZnO}-\mathrm{MnO} \quad(0.5 \mathrm{~mol} \%)$ specimens containing various amounts of $\mathrm{Nb}_{2} \mathrm{O}_{5}$.

るので，添加した $\mathrm{Nb}_{2} \mathrm{O}_{5}$ 量から計算される $3 \mathrm{ZnO}$ $\mathrm{Nb}_{2} \mathrm{O}_{5}$ と残りの $\mathrm{ZnO}$ ，格子定数亡式量加求めた 3 $\mathrm{ZnO} \cdot \mathrm{Nb}_{2} \mathrm{O}_{5}$ の比重, 5.81 と $\mathrm{ZnO}$ の比重, 5.68 で割っ た比率より計算した， $\mathrm{MnO}$ 浱度の测定結果を図 14 に 示す. $\mathrm{ZnO}$ 粒内における $\mathrm{Mn}$ 原子の濃度 $\left(1 \mathrm{~cm}^{3}\right.$ 当た りのモル数）は $\mathrm{Nb}_{2} \mathrm{O}_{5}$ の添加量变化にかかわらずほぼ

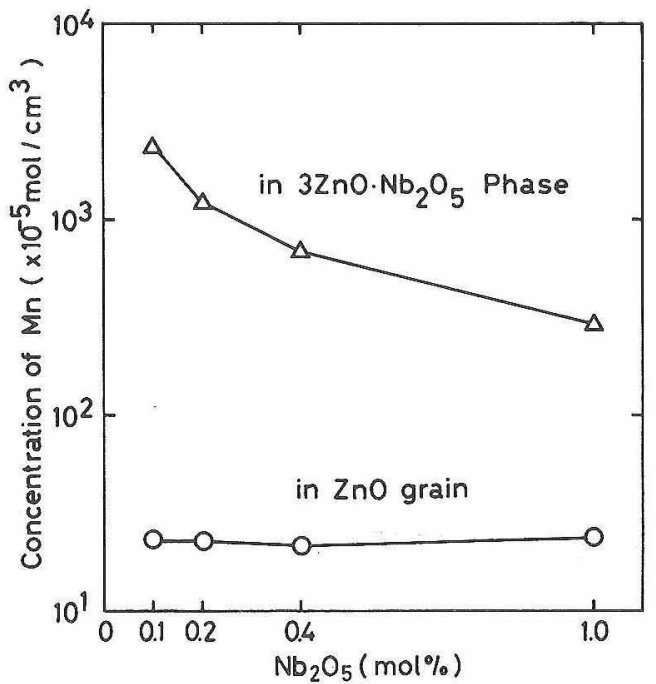

Fig. 14. Effect of $\mathrm{Nb}_{2} \mathrm{O}_{5}$ content on the concentration of $\mathrm{Mn}$ in $\mathrm{ZnO}$ grain and $3 \mathrm{ZnO} \cdot \mathrm{Nb}_{2} \mathrm{O}_{5}$ phase of the $\mathrm{ZnO}$ specimens containing $0.5 \mathrm{~mol} \% \mathrm{MnO}$.
一定であるのに対し，粒界相中における $\mathrm{Mn}$ 原子の濃 度は $\mathrm{Nb}_{2} \mathrm{O}_{5}$ の添加量が増加するに従って，すなわち粒 界相の量が増加するに従って減少する傾向にある。この ことは $\mathrm{Nb}_{2} \mathrm{O}_{5}$ の添加量にかかわらず $\mathrm{ZnO}$ 粒内への $\mathrm{Mn}$ 原子の固溶量が一定であり，余分の $\mathrm{Mn}$ 原子はすべて 粒界相に出てしまうことを示している。したがって図 11 の焼成体の比抵抗值の変化は, $\mathrm{ZnO}$ 粒内の $\mathrm{Mn}$ 原子 の固溶量に起因するものではなく， $\mathrm{n} \mathrm{nO}$ 粒界之粒界相 に関係するものと考えら机る。

$\mathrm{ZnO}$ に $0.5 \mathrm{~mol} \%$ の $\mathrm{MnO}$ のみを添加した試鈳片の比 抵抗は $5.4 \times 10^{4} \Omega \cdot \mathrm{cm}$ と高い值を示したが，この試験 片の粉末 X 線回折結果では, $50 \mathrm{kV}, 200 \mathrm{~mA}$ 亡X 線源 を強くしても $\mathrm{ZnO}$ 以外の回折線は認められなかった。 White 上 McIlvried ${ }^{151}$ は密閉系で $\mathrm{MnO}$ は $1300^{\circ} \mathrm{C} て ゙$ $\mathrm{ZnO}$ に対して約 $25 \mathrm{~mol} \%$ 固溶することを示し, Somiya ら ${ }^{12)}$ も $\mathrm{Mn}_{2} \mathrm{O}_{3}$ は $\mathrm{ZnO}$ に $1300^{\circ} \mathrm{C}$ で $6.7 \mathrm{wt} \%$, $900^{\circ} \mathrm{C}$ で $0.5 \mathrm{wt} \%$ 固溶すると報告している。したがっ て少なくとも $1305^{\circ} \mathrm{C}$ 焼成中では添加した $0.5 \mathrm{~mol} \%$ の $\mathrm{MnO}$ はすべて ZnOに固溶していると考えられ，この 武験片は炬泠中に一部の $\mathrm{MnO}$ が $\mathrm{ZnO}$ 粒界に析出して 比抵抗を高めたのではないかと推定される， $\mathrm{Nb}_{2} \mathrm{O}_{5}$ を添 加した試験片の $\mathrm{ZnO}$ 粒子中の $\mathrm{Mn}$ 濃度が一定であるこ

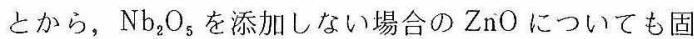
溶量が同じであると仮定すると，その量は $\mathrm{MnO}$ として 
$0.34 \mathrm{~mol} \%(0.30 \mathrm{wt} \%)$ に相当する. 残りの $\mathrm{MnO}$ が $\mathrm{ZnO}$ 粒界に析出するとして析出層の厚さを計算すると, $\mathrm{ZnO}$ が平均 $10 \mu \mathrm{m}$ の球形の場合は $47 \AA$ となる。実際に 析出層が生じる場合は過飽和温度が相当に低いため $\left(900^{\circ} \sim 1000^{\circ} \mathrm{C}\right.$ 付近と推定)，粒界近傍からのみ $\mathrm{MnO}$ が移動しうるので，その析出層の厚さは更に薄いと考え られ，X線試験では検出できないと思われる。

前報 ${ }^{101}$ では $\mathrm{ZnO}$ に $\mathrm{Nb}_{2} \mathrm{O}_{5}$ 在添加すると比抵抗は増加

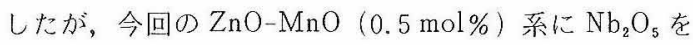
少量添加すると比抵抗は激減した。これは比抵抗を高め る $\mathrm{MnO}$ の析出層が $\mathrm{Nb}_{2} \mathrm{O}_{5}$ 老添加することによって形 成しにくくなっているためではないかと推定される。す なわち, $\mathrm{Nb}_{2} \mathrm{O}_{5}$ の添加で夜相が生成し, その液相は図 15 に示したように焼成中は $\mathrm{ZnO}$ をくぬらして $\mathrm{MnO}$ を取り込みやすくなっており，あるいは既に $\mathrm{MnO}$ を取 り込んでおり（図 14），それらが武験片の炉冷中ぬれ性 が悪くなって $\mathrm{ZnO}$ 粒子の三叉境界等に孤立するように なり，結果として $\mathrm{ZnO}$ 粒子の直接接触が多くなること によるためと思われる。また $\mathrm{Nb}_{2} \mathrm{O}_{5}$ の添加量の増加と ともに比抵抗は増加するが，これは高抵抗である粒界相 が多くなることによると考えられる。しかし $\mathrm{Nb}_{2} \mathrm{O}_{5}$ を $1 \mathrm{~mol} \%$ 添加したものでは再び比抵抗が大きくなってバ リスター特性を示すことについては，この考えの延長で は説明ができなかった。

図 16 は $1 \mathrm{~mol} \%$ の $\mathrm{Nb}_{2} \mathrm{O}_{5}, \quad 0.5 \mathrm{~mol} \%$ の $\mathrm{MnO}$ を添加 した試験片について，焼成温度を変えた場合の非直線性 指数 $\alpha$ と比抵抗值を示したものである. 液相の生成し ない $1250^{\circ} \mathrm{C}, 1$ 時間焼成の試験片では比抵抗值は $1.2 \times$ $10^{4} \Omega \cdot \mathrm{cm}$ で非淔線性はほとんど認められないが，液相 の生成する $1305^{\circ} \mathrm{C}, 1360^{\circ} \mathrm{C}$ 焼成体では比抵抗が一けた 以上増加し， $\alpha$ はそれぞれ 3 及び 4 となって非直線性が 認められる。したがってこの系においては， $\mathrm{ZnO}-\mathrm{Bi}_{2} \mathrm{O}_{3}$ 系と同様に液相の生成が非㨁線性の発現と大きな関連を もつと考えられる：この系のバリスター特性は試験片の

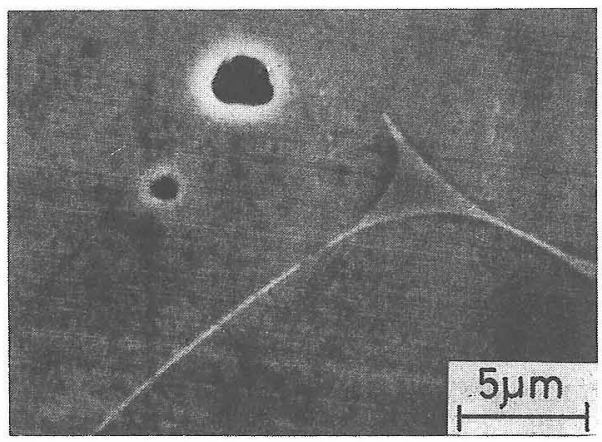

Fig. 15. Scanning electron micrograph of the polished and etched surface of water-quenched $\mathrm{ZnO}$ specimen containing $0.4 \mathrm{~mol} \% \quad \mathrm{Nb}_{2} \mathrm{O}_{5}$ and $0.5 \mathrm{~mol} \%$ $\mathrm{MnO}$.

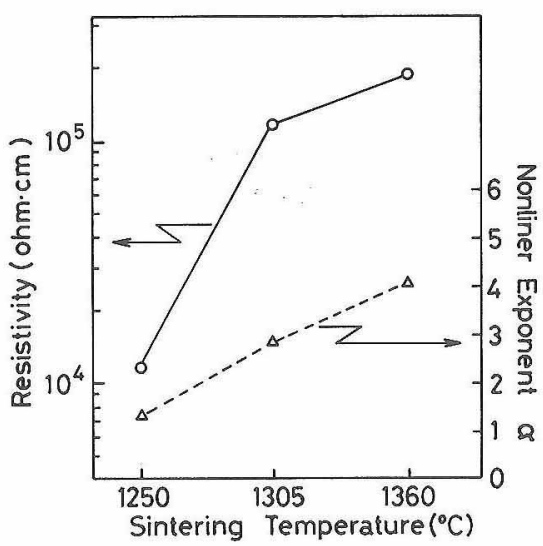

Fig. 16. Effect of firing temperature on roomtemperature electrical resistivity and nonlinear exponent of the $\mathrm{ZnO}$ specimen containing $1.0 \mathrm{~mol} \%$ $\mathrm{Nb}_{2} \mathrm{O}_{5}$ and $0.5 \mathrm{~mol} \% \mathrm{MnO}$.

泠却条件や再加熱によって著しく影響を受けるので，バ リスター特性発現の原因はそれらの観点からも検討する 必要があると思われる。

\section{4. 総括}

焼成中に生成する液相の性質及び液相と固相間の相互 関係を变化させる目的で, $\mathrm{ZnO}-\mathrm{Nb}_{2} \mathrm{O}_{5}$ 系に第 3 成分 $\left(\mathrm{CaO}, \mathrm{SrO}, \mathrm{BaO}, \mathrm{SiO}_{2}, \mathrm{CoO}, \mathrm{MnO}\right) を$ を添加し, こ れらの添加物の挙動や焼成体の微構造及び電気的性質に 与える影響について検討した。

（1）焼成体の比抵抗は，第 3 成分として CoOと $\mathrm{SiO}_{2}$ を添加した武験片ではほとんど变化は認められな いが， $\mathrm{CaO}, \mathrm{SrO}, \mathrm{BaO}$ を添加した試験片では約一けた 半増加した. $\mathrm{MnO}$ を添加した試験片では $\mathrm{MnO}$ の添加 量に伴い比抵抗は急激に増加し，0.5 mol\%の $\mathrm{MnO}$ 添加した試験片においてはバリスター特性が認められた。

(2) 研磨面の組織観察の結果, $\mathrm{CaO}, \mathrm{SrO}, \mathrm{BaO}$, $\mathrm{SiO}_{2}$ を添加した試験片では粒界相の $\mathrm{ZnO}$ 粒子に対する ぬ机性は著しく良くなっているのに対し， $\mathrm{CoO}, \mathrm{MnO}$ を添加した試験片では第 3 成分無添加試料とほとんど変 化がなくぬ姓は良くなかっだ。

( 3 ) $\mathrm{CaO}, \mathrm{SrO}, \mathrm{BaO}$ 在添加した試験片では，それ らの原子は粒界相中に存在し, $\mathrm{CoO} と \mathrm{MnO}$ を添加し た試験片では $\mathrm{ZnO}$ 粒内及び粒界相の両方で検出された。 このうち Mn は粒界相中に濃縮している傾向が認めら れた. $\mathrm{SiO}_{2}$ を添加したものでは， $2 \mathrm{ZnO} \cdot \mathrm{SiO}_{2}$ 相とし て粒界相の一部を構成することが分った。

(4) $\mathrm{ZnO}$ に $0.5 \mathrm{~mol} \%$ の $\mathrm{MnO}$ を添加した試験片は 比抵抗が高く若干のバリスタ一特性が認められたが、こ れに少量の $\mathrm{Nb}_{2} \mathrm{O}_{5}$ を添加すると比抵抗は急激に減少し た. $\mathrm{Nb}_{2} \mathrm{O}_{5}$ の添加量が $1 \mathrm{~mol} \%$ になると再び比抵抗は高 くなってバリスタ一特性を示した。 $\mathrm{ZnO}-\mathrm{Nb}_{2} \mathrm{O}_{5}-\mathrm{MnO}$ 
系では $\mathrm{Nb}_{2} \mathrm{O}_{5}$ の添加量が変化しても $\mathrm{ZnO}$ 粒子中に固溶 している Mnの量にはほとんど変化がなく, 粒界相中 の $\mathrm{Mn}$ の濃度は添加量の増加とともに減少した。 $\mathrm{MnO}$ のみを添加した試験片のバリスタ一特性は $\mathrm{ZnO}$ 粒界に $\mathrm{MnO}$ が折出するためと推定され, これに $\mathrm{Nb}_{2} \mathrm{O}_{5}$ を添加 した試験片のバリスタ一特性は, 液相の生成と関連する ものと考えられた。

謝辞この研究の一部は昭和 57 年度旭硝子工業技術奨励 会の援助によって行った。ここに感謝の意を表します。

\section{文献}

1) M. Matsuoka, Japan J. Appl. Phys., 10,736-46(1971).

2) 例えば, 一ノ瀬 昇・大熊英夫, 七ラミックス, 11, 205-11 (1976).

3）早川 茂・飯田義男, セラミックス， 8，578-86 (1973).

4) 例えば, M. Inada, Japan J. Appl. Phys., 17,1-10(1978)
;17, 673-77 (1978).

5) W. G. Morris, J. Am. Ceram. Soc., 56, 360-64 (1973).

6) J. Wong, J. Am. Ceram. Soc., 57, 357-59 (1974).

7) J. Wong and W. G. Morris, Am. Ceram. Soc. Bull., 53, 816-20 (1974).

8) J. Wong, J. Appl. Phys., 51, 4453-59 (1980).

9) S.R. Sainkar, S. Badrinarayanan and A.P.B. Shinha, Appl. Phys. Lett., 39, 65-66 (1981).

10）浜野健也, 佐谷野顕生, 中川善兵衛, 善協, 91, 309-17 (1983).

11）高田雅介 - 坪根大輔 - 柳田博明, 㝘協, 82, 271-77 (1974).

12) S. Somiya, S. Hirano and H. Fukuyo, Report of RLEMTIT, No. 3, 79-86 (1978).

13) H. Brusset, R. Mahé and U. Aung Kyi, Mater. Res. Bull. , 17, 1061-74 (1972).

14) M. Isobe, F. Marumo, S. Iwai and Y. Kondo, Bull. Tokyo Inst. Tech., No. 120 Report of RLEM No. 12, 1-6 (1974).

15) W. B. White and K.W. McIlvried, Trans. Brit. Ceram. Soc., 64, 521-30 (1965). 